\title{
Thai Entourage Politics in the Socialist State of Vietnam
}

\author{
Ha Viet Quan
}

\section{Introduction}

We arrived at Lò Vi An's house in Châu La Biên, ${ }^{1}$ a northwest province, quite late from Hà Nội because the lunch-stop at Châu Quỳnh town took much longer than we had planned. Lò Vi An seemed a bit tired from the rice wine during lunch but he was satisfied with the warm hospitality provided by Cầm Chung, a Thai leader of Châu Quỳnh District, and his entourage. Lò Vi An's house impressed me with its luxurious interior: a big garage, digital security camera system, elevator, and other modern appointments. However, as soon as I crossed the living room with its Western-style furniture, such as a leather sofa, crystal glasses, and gold-plated tea set, I was surprised by the kitchen with its traditional Thai cooking utensils, including several rice baskets (cam khao), wooden rice steamers (mo nuung khao), and bamboo vegetable steamer (mo nuung phac). In a corner of the kitchen, I saw Toàn, an adopted son of Lò Vi An, roasting a piece of dried buffalo skin in a wood-fired stove. As I already knew Toàn, I greeted him and the others in the kitchen by saying how impressed I was by one of the dishes they were preparing: 'Wow! It looks like

1 Châu La Biên is a pseudonym. All place names relating to Châu La Biên and the names of Thai cadres and their associates in this chapter are pseudonyms. 
we are going to have nom nang quai [a Thai-style buffalo skin salad]. It's my Dad's favourite.' Toàn handed up a piece of dried buffalo skin and asked me in Thai: 'Australians don't eat this special stuff, do they?' 'No, they don't. It is too luxurious for them!' I responded jokingly, and while we were all chuckling, Toàn introduced me briefly to his companions as a student studying in Australia. He then turned the topic to how traditional Thai foods and Thai restaurants are becoming popular with the Kinh people (Vietnamese) in Hà Nội.

The appearance of Lò Vi An in the kitchen interrupted the story Ly was telling about her business trip to Hà Nội the previous week. Ly is Toàn's wife, who I had met once at Lò Vi An's house in Hà Nội. She looks quite young for the position of Deputy Head of Châu La Biên Rural Development Department. Dressed like a Kinh, and speaking Vietnamese, it is nevertheless not difficult to tell that Ly is a Thai woman because of her strong Thai accent. Lò Vi An sat down next to me while I was helping Toàn to slice buffalo skin. He took the kitchen knife from me to demonstrate how to slice it properly. Lò Vi An then asked Ly, without looking at her, in a mixture of Thai and Vietnamese: 'Does Trung still drink, Ly? Call him to come here to have a couple of drinks' ('Ba Trung kin lau day bo Ly? Gọi nó đến kin lau đi'). Ly responded that her brother, Mr Trung, who I came to know later as her eldest brother and an officer of the Provincial Communist Party of Châu La Biên, would come for dinner because he too wanted to see Lò Vi An. Putting his hands on his knees, Lò Vi An slowly stood up, and scanning around the kitchen and looking at his watch, he announced as if giving an order, 'Let's make the dinner ready around 6:30pm guys!', then left.

Lò Vi An was a leading official of Châu La Biên Province, which is situated in one of the traditional Thai homelands in Vietnam. ${ }^{2}$ He moved to Hà Nội in 2003 to work as head of a national agency. Like most provincial leaders who are promoted to work at the national level, his wife and children also moved to live in the capital city. However, An kept mentioning that he would be going back to Châu La Biên as soon as he retired from work: 'I don't have any thought that I could permanently live in Hà Nội. It is too crowded and polluted.'

2 The muang - glossed here as homeland — is the traditional socio-spatial and political unit of the Tai in the uplands of mainland South East Asia (Condominas 1990). Historically, within Vietnam there have been 12 muang, known as Sip Song Chau Thai. 
That explained why he had spent a lot of money recently renovating his house in Châu La Biên. Even though he works in Hà Nội, Lò Vi An was very well respected in his home town. Talking about his adoptive father's influence in Châu La Biên, Toàn assured me:

You don't have to worry about your interviews, they all know my Dad so just tell whoever you want to talk with that my Dad [Lò Vi An] says it's OK. If you want to see Thai cadres, I know many of them. They are either our relatives or my Dad's followers [đệ tử], therefore, you will not only be welcome to interview them but also invited to drink!

Indeed, most of the Thai cadres whom I met through Toàn and Lò Vi An during my fieldwork in Châu La Biên are, in one way or another, tightly connected with Lò Vi An. This was the case of Cầm Chung. He told me: 'Without the support of big brother [dai ca] An, I would not be able to achieve what I have today.' Cầm Chung used to work as a planning expert of Châu La Biên Provincial Office before being selected by Lò Vi An to be his private secretary for three years. He was then promoted (with support from Lò Vi An) to be Vice Chairman of Châu La Biên Provincial People's Committee Office, then Chairman of the District People's Committee of Châu Quỳnh District. He is apparently linked with Lò Vi An by a classic patron-client relationship.

However, it seems that Thai cadres such as Cầm Chung, Toàn, Ly, Trung and others in Châu La Biên are not simply tied to Lò Vi An by the traditional patron-client dyadic which, according to Scott's research in Southeast Asia, involves 'a largely instrumental friendship' (Scott 1972:92). They are also connected with him and with each other by primordial bonds such as kinship, ethnicity and language. These ties have been used as a means for Thai cadres to press advantage and maintain autonomy in dealing with the centralised nation-state's administrative structures. The presence of this tight-knit network of Thai cadres in Châu La Biên challenges a prevailing view of Vietnam's socialist state as dominating, monolithic, and assimilatory in its treatment of minority groups (Evans 1992; McLeod 1999; McElwee 2004; Lentz 2011). It also confronts the view that the agency available to Vietnam's ethnic minorities is confined to responses such as ethnonationalism, religious conversion, passive resistance, and flight (Hickey 1982; Salemink 2003; Taylor 2008; Scott 2009). Instead, the Thai cadres grouping around Lò Vi An comprises an alternative 
way to advance Thai interests by participating in the state, taking advantage of their positions within the state system, and using the state's resources to achieve their goals and realise positive outcomes.

Studying minority projects in the borderlands, Horstmann and Wadley (2006:19) argue that if anthropologists focus on the concrete interactions between minorities and state power and on the local reworking of national and global scripts, it becomes possible to see how people on the periphery give meaning to and shape their own marginal spaces, and deal with state power. Marginal communities may be able to employ certain existing linkages or develop networks in order to maintain their relative cultural autonomy and to influence state plans in their localities. In another example, the Chinese in Thailand, and in many other countries, are a minority group; however, they continued to dominate the Thai economy through their extensive networks. As Chayan Vaddhanaphuti says: 'Identifying themselves as Thai, having adopted Thai names, embracing Buddhism, they, nonetheless, still retained their Chinese traditions' (Vaddhanaphuti 2005:154).

In Vietnam and in adjacent border areas, some research has been conducted on the vernacular networks of ethnic minorities through religion and trade, such as the translocal networks of minority Cham Muslims in central and southern Vietnam (Farouk and Yamamoto 2008), Hmong women's trade networks in the Sino-Vietnamese borderlands (Turner 2007), and Hmong girls' tourism networks in Sa Pa (Hanh 2008). The scale and vibrancy of these networks contradict the view that ethnic minorities are localised and autarchic, and challenge the image of ethnic minorities as impotent, dependent, or incompetent (Hardy 2005; Taylor 2008). These networks do not necessarily undermine the state's attempts to achieve unification and development, nor do they replicate them; instead, they allow minorities to build up resources and develop their own culture, institutions, and the values that define them. In this research, I do not aim to judge either the national political system or the Thai people in Châu La Biên. Instead, I will recount how the minority Thais in the northwest of Vietnam consolidate their own position, institutions, and values by participating in the state of Vietnam. Since this research is based on the case of a single senior cadre and his entourage, it does not claim to be representative of the behaviour and networks of all Thai elites throughout the northwest of 
Vietnam. However, the case does shed light on previously unexamined aspects of the political life of northwest Thai elites that challenge the way the Thai-central relationship has been construed.

This chapter initially looks at the conceptualisation of a Thai leader among Thai cadres in the northwest of Vietnam. It then provides information about his network by asking who its members are, how they are connected, and in what circumstances. The third part analyses the nature of this Thai network and explores how the northwest Thai people domesticate state power to obtain autonomy, dignity, and enrichment within the state of Vietnam. In this section, I explore a mode of entourage politics adopted by northwest Thai cadres, who use their respective positions, powers and responsibilities in the Vietnamese state to support other members and build and preserve influence. The conclusion provides a concise argument about the relationship between the minority Thai group and the state of Vietnam. ${ }^{3}$

\section{Taking Advantage of the State: Conceptions of a Thai Leader}

The dinner held at Lò Vi An's house was a great chance for me to approach Thai cadres in Châu La Biên. Among the guests, most of whom were Thai officers working for different provincial departments of Châu La Biên, were two Kinh contractors, who accompanied Lường Trung (Ly's brother) to the feast. Despite the Western-style dining table, the dinner was very traditional, as most of the food was Thai. Lò Vi An invited his brother-in-law Cầm Tuấn, the eldest brother of his wife, to sit at the centre of the dining table with him. After pouring rice wine into two extra cups as wine for ancestors (lau then), he tipped wine into Cầm Tuấn's cup and his own, then handed the bottle to Toàn to pour wine for everyone else. Lò Vi An put his little finger into his cup, flicked wine over both his right and left shoulders then said in a mixture of Thai and Vietnamese language: 'Going out to eat fish, going home to drink wine. All are brothers and sisters in

3 The fieldwork on which this chapter is based was conducted over the course of 2013 as part of my doctoral research at The Australian National University, funded by an Australia Awards scholarship. I wish to thank Philip Taylor, Nicholas Tapp, Andy Kipnis, Kim Wells, and the two anonymous reviewers for their valuable feedback and assistance with this chapter. 
the family, no one is an outsider so don't be formal: let's finish the first round!' ('Pay - kin pa, ma - kin lau. Toàn anh em trong nhà cả thôi, không có ai la người ngoài cả, đừng khách sáo. Au heng!'). He bottomed up his cup after Cầm Tuấn, then showed his empty cup for everyone to follow.

Lò Vi An is the eldest son of an intellectual Thai family (con nhà nòi) in Châu Quỳnh, Châu La Biên. His grandfather was a village noble (phia) who had supported the Việt Minh during the war against the French ${ }^{4}$ and his father was a high profile Thai leader of the former Administrative Committee of the Northwest Autonomous Zone. Thanks to his father's position in the local state, An and his brothers and sisters had associated with Kinh people from a very early age, so he could speak Vietnamese even before going to school.

In reality, since the early 1960s, as the state of Vietnam implemented its drive towards being a model socialist country, many Kinh teachers were sent up to the northern mountainous areas to build up the general education system for ethnic minority children. Most of them could not speak the local language, and were also unfamiliar with traditional customs and culture, and the highland lifestyle. Hence, the Kinh teachers had to more or less rely on the locals for building schools and mobilising support from local people in the form of foodstuff, labour, and materials for building the schools.

4 In scholarship on the northwest Thai region, a common perspective is that Thai nobles tended to follow the colonial French, and were subsequently eliminated as a class or exiled after the revolution. Some scholars of the northwest during the colonial era focus on the role that Thai elites played in sustaining French rule (Le Failler 2011; Michaud 2009; Michaud 2013:6670). Others see the revolution as essentially a form of Kinh internal colonialism (McLeod 1999). I did not have enough time to investigate this aspect of regional history in depth, but during fieldwork, in addition to Lò Vi An, I met at least three senior Thai officials who also came from noble families and who similarly claimed that their families were Việt Minh followers. Lò Vi An's family history is not necessarily typical, but I would not see it as an isolated case in the northwest region. In reality, many notable northwest Thai leaders from noble families lent their support to the Việt Minh movement, then became senior officials, including Cầm Văn Thịnh, Cầm Văn Dung, Xa Văn Minh, and Cầm Ngoan (for more examples, see Lentz 2011). According to Cam Trong (1978:511-517), there had been a clear strategy on the part of the Việt Minh from 1941-45 to mobilise the noble Thais to participate in the anticolonial movement in Sơn La Province. I would argue that the Thai elites who rallied to the revolution played a vital role in the story of how the lowland-based and Kinh-dominated Việt Minh gained a foothold in the mountainous northwest of Vietnam. 
Lò Vi An's Kinh teachers remembered him as a versatile and adept Thai student (khéo tay, biết làm nhiều việc) who knew how to build bamboo classrooms, houses, bamboo beds, and other school facilities from local materials. Trần Văn Thuấn, one of Lò Vi An's Kinh high school teachers in Thuận Châu, recalled: 'He was a Thai so he knew how to do things in Thai ways, which we young Kinh teachers couldn't do.' Trần Văn Thuấn also said that he and his colleagues were charged with setting up their own school in Châu La Biên, but they could not speak much Thai language, and most of the Thai people did not speak Vietnamese either. Lò Vi An and a couple of senior students were conscripted into helping the teachers work with the local Thai people in mobilising local kids to go to school, helping kitchen staff to buy foodstuffs from local people, calling for help from local authorities in building classrooms, and so on. It seemed that his local knowledge allowed Lò Vi An to play a much more important role for his Kinh teachers than simply being a Thai student.

In his Thai friends' eyes, Lò Vi An was highly appreciated as a friendly (hòa đồng) schoolboy who did not depend on his father's influence (không ý lại/dựa hơi bố). However, they believed that he had benefited significantly as the son of a man who had been a high profile leader of Châu La Biên since Lò Vi An was a child. He was one of a very few local Thai kids who could speak Vietnamese before going to school. With this language advantage, Lò Vi An was not only a good student himself but was also assigned by his teachers to help other Thai students in his classes. According to his high school friends in Châu La Biên, Lò Vi An was an active Youth Union leader (cán bộ Đoàn năng nố). 'He was also a sporty guy, a good volleyball player. I remembered he used to play volleyball with teachers after classes', a high school friend recalled. Generally, Lò Vi An was remembered by his school friends as a prominent Thai student who came from a noble lineage, spoke Vietnamese well (thạo tiếng phổ thông), and had been closely associated with the Vietnamese teachers.

Lò Vi An was sent to study for a bachelor degree at Bắc Thái Pedagogy University after graduating from the Northwest Ethnic Minorities Youth School in Thuận Châu, Sơn La. The path to becoming a cadre of the central planned economy state during the late 1970s and 1980s seemed smooth for An. Firstly, because of educational policies for ethnic minorities in Vietnam (chinh sách cử tuyển), he did not have to attend the admission exams to go to university like his Kinh 
schoolmates. It was very common in Vietnam for most ethnic minority students to be sent by their provinces to study at different universities and colleges in line with the fixed quotas set by the central state agencies. Secondly, because of the huge demand for general education teachers in the northwest provinces, Lò Vi An was promptly posted as a lecturer in the newly formed Northwest Pedagogy College in Châu La Biên upon graduation from university.

In the role of lecturer to many local general teachers at the Northwest Pedagogy College, Lò Vi An was widely seen as a young Thai intellectual who not only came from a noble lineage (con quan), but also as a welltrained (được đào tạo bài bản) Thai cadre of Châu La Biên. He quickly began his political career by taking up the position of Director of the Provincial Education Department of Châu La Biên from the late 1990s. From there onwards, he occupied different positions in the local state of Châu La Biên, such as Chairman of a District People's Committee, Vice Chairman of the Provincial People's Committee, and as one of the top leaders of Châu La Biên Province, before moving to Hà Nội to work at the central level. ${ }^{5}$

There was a rumour in Châu La Biên that Lò Vi An was in fact 'kicked upstairs' to the central level in Hà Nội by his political opponents because of his corrupt activities when he had been a provincial leader. There is also a popular saying in Vietnam about ranking in the government system: 'Better to be the head of a chicken than the cheek of a pig' ('Đầu gà hơn má lợn'). ${ }^{6}$ However, because of the complexity of the political system in Vietnam - namely, relations between the Communist Party, People Council, and the government agencies at different levels - one cannot really ascertain if the rumour is true or not. However, in the eyes of the Thai cadres, Lò Vi An was obviously an influential provincial leader.

Having risen from college teacher to Thai politician, Lò Vi An was a well-respected intellectual Thai leader. Among popular comments that I heard about Lò Vi An, terms such as 'formally educated cadre' (được đào tạo bài bản), 'capable official' (có năng lực), and 'knowledgeable Thai leader' (hiểu biết) were common. Similarly, as a descendant from a Thai

5 In order to protect the identity of my key informants, I have listed the positions in which Lò Vi An has occupied in a different order.

6 In English this would be more akin to 'Better to be the head of a dog than the tail of a lion'. 
cadre family, Lò Vi An was greatly appreciated for his familiarity with the state of Vietnam. This appears to have been one of his strongest assets as a Thai leader from several viewpoints. Firstly, Lò Vi An was trusted by the state because of his family tradition, his father having been a former leader of the Northwest Autonomous Zone. Lò Vi An was perceived as a Thai leader who had close relationships not only with the top national leaders, but also with the central agencies. Secondly, with his family's contribution to nation-building, his opinions - according to the Thai people - were carefully heard by the central state. Last, but not least, his understanding of the working of the Vietnamese state made him - in the view of local Thai cadres - a capable and worldly-wise Thai official. This helped him take advantage of being a state cadre to fulfil the needs of the local people.

Even though he had been working in Hà Nội for years, An appeared to follow a traditional Thai lifestyle: eating mostly sticky rice and traditional Thai foods, and preferring to speak Thai at home. In Châu La Biên, he was described by local Thai cadres as a leader who cared for both economic and cultural aspects of the province's development. Many Thai cadres compared Lò Vi An to a captain, who had steered Châu La Biên to become the capital province of the northwest territory of Vietnam. He was also very proud of Châu La Biên's cultural and social achievements promoted by the Northwest Culture Fest, which has been held every two years since 2003. He stated:

I was the one who initiated the Northwest Culture Fest. Without it Châu La Biên Province would not be remembered nationwide and in the minds of national leaders. It is the Culture Fest which promotes the image of Châu La Biên to the country. Being a leader, you have got to know what are the advantages and disadvantages of your province. You have to know that a mountainous province like Châu La Biên, in comparison to other lowland provinces like Bắc Ninh, Hải Phòng and Hòa Bình, can't be famous for its economical potential but for its typical cultural values.

Interestingly, from his own point of view, Lò Vi An considered the Culture Fest as not simply a cultural activity. He seemed to be more proud of his use of the Fest as a political means to attract the attention of outsiders, especially national leaders, to his province. 
Lò Vi An's relationship with the central leaders was one of relative strength. In response to my question as to what made Lò Vi An a good leader, the majority of the Thai cadres I met in Châu La Biên believed that Lò Vi An's ability to work with the central agencies was an asset. This aspect was highly valued by the local Thai cadres. They mentioned to me several times that during An's presidency many national leaders had visited Châu La Biên. Lường Trung complained: 'Unlike when the big boss (sếp) Lò Vi An worked here, no top national leaders visit Châu La Biên these days.' According to the local Thai cadres, Lò Vi An's good relations with the administrative centre (quan hệ tốt với trung ương) allowed him to channel state resources to the Thai people. 'He was able to call for many investments from central agencies into Châu La Biên', said Lường Trung. Similarly, Cầm Chung overstated at the lunch-stop at Châu Quỳnh that Châu La Biên should build a statue to Lò Vi An, considering all that he had contributed to the province. He said: 'Very few people know it but I do. He [Lò Vi An] took the advantage of the construction of a major hydropower project to develop massively the infrastructure of Châu La Biên.' ${ }^{7}$

Studying leadership perceptions and attribution of charisma to the leader, Lord and Maher (2002) argue that the power of leaders is fundamentally related to how they are perceived by others, and leaders' characteristics are based on outcomes of salient events. According to Ensaria and Murphy (2003:61), 'a high outcome produces greater attribution of charisma to the leader'. Apparently, the leadership of Lò Vi An was closely associated with the outcomes of the promotion of Thai culture, and infrastructure development in Châu La Biên (when he was working there). His influence was perceived by local Thai cadres as stemming from his good relations with the Vietnamese state, somewhat similar to his school friends' recollection of him as a prominent Thai student who was closely associated with their Vietnamese teachers.

Standing between the Vietnamese state and the Thai people, Lò Vi An appeared as a cultural intermediary or cultural broker who, according to Wolf (1956), Bonacich (1973), Moerman (1969:546), and Szasz

7 Sơn La Dam is a concrete gravity dam on the Black River (sông Đà) in Ít Ong, Mường La District, Sơn La Province, Vietnam. It is the largest hydroelectric power station in Southeast Asia. It has a total capacity of 2,400 MW with an expected annual generation of 10,246 GWh. The total cost of the project was \$2 billion USD (Bui, Schreinemachers and Berger 2013:537). 
(2001), played the role of a middleman. He used his Thai ethnicity to build up his relationships with the Vietnamese state which always needed Thai support for its multicultural project (Ngo 1997:139-141; Nguyễn 1975:9). By acting as a Thai 'foreign minister', symbolising the Thai people to the national state, An was designated authority and power by the Vietnamese state to secure and maintain his leadership among local Thai people. Importantly, his association with the majority Vietnamese did not make Lò Vi An a 'Vietnamised' Thai cadre in their eyes. Instead, by virtue of his notable work achievements such as the Northwest Culture Fest, the province university, and other infrastructure projects, the Thai people in Châu La Biên perceived Lò Vi An as a charismatic leader because he had the ability to deal with and take advantage of the state of Vietnam to fulfil their needs.

\section{Brothers in a Family: The Nature of a Thai Cadre Grouping in Northwest Vietnam}

In a car with the engine running, waiting at the clubhouse of a golf course outside Hà Nội, Huy - Lò Vi An's private driver, who is also a distant relative of Lò Vi An's wife - seemed a bit anxious. He mumbled: 'My goodness, what are they talking about that takes so long over there? We can't stop here much longer.' Huy was anxious because he was parked in the pick-up and drop-off area in front of the clubhouse entrance. Lò Vi An had finished playing, but he had met some friends on the way out and had stopped to talk with them. I chatted to while away the time with Huy, who had been driving for Lò Vi An for more than 15 years since he had been posted to Châu La Biên. I heard some interesting observations from Huy during our short conversation:

Me: How often do you and the boss go to Châu La Biên?

Huy: Quite often. Whenever he has free time he returns home [về quê] [Châu La Biên]. When he was renovating his house a couple of months ago, we travelled to Hà Nội — Châu La Biên — Hà Nội almost every week.

Me: Oh. It seems that the boss can't wait to enjoy being in his new house. He must love living in Châu La Biên very much, right? 
Huy: Of course, Châu La Biên is his territory. His life is as good as a king in Châu La Biên, because his family, relatives [anh em, họ hàng] are all still there. Policemen up there never pull my car over.

Me: Really? I thought he had moved to Hà Nội already so he was no longer in power there.

Huy: Oh. Don't be fooled by the boss [đừng có đùa với sếp]. He has had a long-term strategic view about personnel arrangements in Châu La Biên since he was a leader there. Up there, provincial officials are mostly like brothers in a family [toàn anh em trong nhà].

Huy's comment made me take notice. The Châu La Biên Thai cadres grouped around Lò Vi An were indeed connected to him mostly by either kinship or adoptive relations. Commonly, they referred to themselves as brothers in a family (anh em trong nhà) in speaking both with Lò Vi An and among themselves. Moreover, looking at the daily activities of those Thai cadres, one could also agree with Huy that Lò Vi An, as a Thai leader, had a long-term vision to maintain not only his influence, but also Thai culture in the local state system of Châu La Biên via his entourage. I had a chance to experience these arguments, right at the dinner at Lò Vi An's house, especially when they were discussing implementation of some infrastructure development projects.

Over almost three decades since the economic reform named đổ $i$ mới, Vietnam has experienced dramatic economic growth, which has led to considerable poverty reduction programmes and policies nationwide (Salomon and Ket 2007; Baulch et al. 2010; Blackburn et al. 2006). Châu La Biên, like most other mountainous provinces in Vietnam, has enjoyed sizable state investments for infrastructure development (Baulch et al. 2012). As a result, the relationship between construction contractors and the local authorities is very dynamic because construction is one of the most profitable businesses in Vietnam (Nguyen and van Dijk 2012). I was told by some private construction contractors that they sometimes accrued a 50 per cent profit out of the total investment budget from infrastructure building contracts. Apparently, infrastructure development is one of the most attractive businesses in the north of Vietnam not only for contractors but also for government officials. 
In fact, one of the main topics discussed during dinner at Lò Vi An's house was the government infrastructure development program in Châu La Biên. Lường Trung brought along two contractors to introduce them to Lò Vi An as capable and potential building partners. He wanted Lò Vi An to help them get infrastructure development contracts by using his influence at both central and provincial level. Giving the man sitting next to him a slap on his shoulder, he delivered an endorsement to Lò Vi An:

Tú [one of the two men he brought to dinner] is the husband of my wife's cousin, and his company has many construction contracts in Laos so they are a very capable construction contractor. More importantly, they are my brothers so they can't escape anywhere. We don't have to worry for anything.

Lường Trung cleverly used the phrase 'they can't escape anywhere', to assure Lò Vi An that the contractors would be responsible for what they do with their contracts. However, it also contained a deep implication that because they are brothers, they would be responsible for sharing any commission derived from the contracts. Lường Trung mentioned several situations in which some contractors had run away after finishing their contracted work. In other words, they did not share the commission with those who had helped them get the contracts. Lường Trung described them as 'unfaithful' people. He said, 'There are many contractors, but many of them are unfaithful. They often kick the bowl that feeds them [ăn cháo đá bát].' Signalling Toàn to pour wine for everyone, Lường Trung continued: 'It is very hard to trust outsiders nowadays.' He then proposed that all present share a drink as 'brothers of one family' (em mời tất cả các anh em trong nhà một chén), emphasising the contractors' familial relationship to the others in his toast.

Lường Trung and Lò Vi An share an affinal relationship - the former being a brother of Lường Ly, who is Toàn's wife. While Lường Trung was well respected by most of the group's members, Lò Lam, youngest brother of Lò Vi An, described him as an opportunistic man who took advantage of his brother's influence to make money out of many corrupt activities. However, Lường Trung seemed to have gained the trust of Lò Vi An, mostly as a middleman, in carrying out infrastructure development projects in Châu La Biên, where he had no formal position of power. 
I had the chance to visit Lường Trung at his well-decorated townhouse in a central street of Châu La Biên City, but I did not have much time to talk with him. I managed to visit Lường Trung again in his Châu La Biên Communist Party office on a cold winter morning around Tết (Vietnamese New Year festival). In contrast with his house, Lường Trung's office was rather simple, with several souvenir pennants from badminton tournaments, a couple of personal merit certificates and other awards hanging on the wall. In an old documents cabinet, there was nothing but some thin books and a jar of herbal wine.

Showing me a warm welcome, Lường Trung poured wine into two teacups, gave one to me and said, 'Tea is useless in this kind of weather; this drink will keep you warm'. I took the cup and sought more information about his relation with Lò Vi An by saying: 'You seem to be very much favoured by the big boss [Lò Vi An]. When we spoke, he appreciated you highly.' Lường Trung responded modestly, 'Oh! We are brothers in a family [anh em trong một nhà cả]. But he appreciates you highly too.' We spent more than an hour chatting about his relationship with Lò Vi An and other Thai people in Châu La Biên. Lường Trung appeared to know a lot about the history of Thai people in Châu La Biên as well as in the northwest region of Vietnam, which is rare among the current generation of Thai people. He was very keen to share with me how Lò Vi An was a good Thai leader not only to him, but also to many other Thai cadres. He stressed the fact that, thanks to the leadership of Lò Vi An, Châu La Biên had developed infrastructure - particularly many road improvements. Lường Trung listed Lò Vi An's vision for the expansion of Châu La Biên City, his ideas to build a university and different colleges, turning Châu La Biên into a centre of the northwest area, and a number of other initiatives as valuable achievements. These were all common claims about Lò Vi An's achievements that I had heard before. He closed the conversation by reiterating that, 'Lò Vi An's greatest asset is his strategic view. He is a real big brother to us, who not only supports us, but also connects us together [quy tu anh em].'

Lường Trung was busy during the late morning. A couple of guests came in to say happy New Year and give him some Tết presents. In addition, several calls came in on his landline and cell phone to invite him for lunch. Lường Trung explained to me that he had to deny them all because, 'I promised to drink with a group of Châu Quỳnh District officials at Cầm Chung's house. We are brothers in a 
family [là chỗ anh em với nhau] so I cannot cancel it.' He invited me to join the lunch with them, by focusing on the 'family connection' again, 'there are no outsiders; all are brothers in a family [toàn anh em trong nhà]'. I told him that I needed to inform Toàn and Ly, because they might wait for me for lunch at home (I was staying at Lò Vi An's house). 'Don't worry, I will call them to join us there [Cầm Chung's house] too.' Lường Trung showed his power over Toàn and Ly as their brother by giving them an order to come to the lunch at Cầm Chung's house.

I realised that among the members of the Thai grouping around Lò Vi An, a complex hierarchy enabled some members to wield influence over others. Sometimes the status of a member is based on his or her position in the Vietnamese official hierarchy, but most of the time it is based on their family relations. Ly's relation with Lường Trung is a case in point. As deputy head of a provincial department of Châu La Biên, her position was apparently higher than her brother's in the local state system. However, she had very little power or influence over her brother Lường Trung. Similarly, her husband Toàn had a high position as Vice Director of the Social Policy Bank of Châu La Biên. However, since Toàn is an adoptive son of Lò Vi An, he appeared to have very low status in relation to other members in the group, who he had to address as uncle, aunty, older brother, and so on.

We arrived at Cầm Chung's house in a small street of Châu La Biên City. It was an old house located on a relatively large piece of land. The house even had a little fish pool, a small drying ground in the front, and a separate kitchen house at the back. Because Cầm Chung had been working in Châu Quỳnh District more than 100 kilometres away from his house in Châu La Biên, he did not come home very often. I was told by Lò Vi An that he was expecting to be moved back to the provincial level in early $2014 .^{8}$

Cầm Chung was decanting rice wine into small bottles in the living room, while people were still steaming sticky rice and preparing food in the kitchen. Unlike in the Kinh area in Hà Nội, in Châu La Biên, Thai men are the main cooks when it comes to a big feast or a party.

8 According to the latest news I have received from Vietnam, Cầm Chung could not return to the provincial level because of political reasons and had already moved to work for a central agency in Hà Nội with the support of Lò Vi An. 
Even powerful leaders in the state system such as Lò Vi An, Cầm Chung, or Lường Trung are likely to be found in the kitchen cooking and preparing Thai dishes. Cầm Chung was delighted to see Lường Trung and I joining the lunch. As I already knew Cầm Chung, I went directly over to give him a hand decanting wine while Lường Trung entered the kitchen with the cooks.

Similar to other feasts in which I participated in Châu La Biên, the lunch at Cầm Chung's house started with a short speech by the host to say that he had not invited outsiders: all the diners were close brothers. I was invited to sit as an honoured guest next to Cầm Chung and Lường Trung, who were the oldest people present. Generally, Thai people in the northwest of Vietnam still observe a hierarchy system, based on age and family relations, to determine the positions of people at a dining table.

Among the group of Thai cadres I met around Lò Vi An, Cầm Chung was one of very few Thais not connected to Lò Vi An through a real family relation. His connection with Lò Vi An began as a patronclient relationship when selected by Lò Vi An to work as his private secretary. Nevertheless, Cầm Chung eventually became like a brother of Lò Vi An since he identified himself as a 'lifetime client' in relation to Lò Vi An. In fact, Cầm Chung was well-cherished not only by Lò Vi An, but his family members as well. In an informal discussion with Lò Vi An's wife in Hà Nội, I remember that she appreciated the connection between Cầm Chung and Lò Vi An because 'it had been tested over the course of time'. She mentioned that even though Cầm Chung's family was in Châu La Biên and he was working as a leader of Châu Quỳnh, he participated in most of the important events at Lò Vi An's house, regardless of whether it was in Hà Nội or Châu La Biên. Lò Vi An said of his bond with Cầm Chung: 'This is a real brothers [pi-nong] relationship of the Thai people', and quoted a Thai saying: 'Brothers are like water, they cannot be cut by a knife; aren't divided even in nine different markets' ('Pi nong tat cong lin, bau khat; toc cau lat bau xia'). ${ }^{9}$

9 This implies broad geographical dispersion in distant and unfamiliar places, 'markets' referring to higher-level centres or towns that serve a network of villages. 
Similar to Cầm Chung, Nguyễn Toàn is connected with Lò Vi An by proven ties of trust. However, familial intimacy and mutual obligation colour the relation between Nguyễn Toàn and Lò Vi An, because he is also a relative of Lò Vi An's wife. Initially, Nguyễn Toàn was adopted into Lò Vi An's family in Châu La Biên basically to help them do housework. In return, he was sent to Châu La Biên High School to continue his education. Having spent most of his younger life living with Lò Vi An's family, Nguyễn Toàn pursued his full family member status as an 'adoptive son' (in Thai: luc leeng) of Lò Vi An. ${ }^{10}$ The influence of his adoptive father acted to smooth his path to becoming a provincial official.

Lò Vi An has two brothers and two sisters. I know them all personally. Three of them are state cadres, including one vice chairman of a district people's council, one deputy head of division of a local branch of the state bank of Vietnam, and one general director (giám đốc sở) of a provincial department. In addition his siblings, Lò Vi An and Nguyễn Toàn wrote down an incomplete interview list comprising 14 other relatives who were provincial and district officials. According to Lò Vi An, the Thai people have culturally a strong connection among relatives. He quoted a Thai saying to describe the connections with his entourage: 'If they are not brothers, they would be sisters; if they aren't consanguineal relatives, they would be affinal relatives; if not cousins on the mother's side, they would be aunties on the father's side' ('bau ai co noong, bau lung co ta, bau nhinh co sao'). I could not interview all of those 14 Thai cadres during my fieldwork. However, the list of the Thai interviewees impressed me greatly by presenting a picture of how dominant this Thai extended family could be over the local state of Châu La Biên. In total, they have representatives in leading positions spread out over seven different provincial departments and four districts.

10 Similar to the Thai-Lao language term which has been analysed by Keyes (1975), the term 'luc leeng' means 'child to feed and take care of'. It is somewhat similar to 'con nuôi' in Vietnamese or 'adoptive son' in English. In accordance with Keyes's analysis, Toàn could also be described as a 'foster child' of Lò Vi An. However, in this research, I prefer to use the term 'adoptive' to describe the process of recruiting and developing members into the grouping of Thai cadres around Lò Vi An. 


\section{Contentious Connections}

It was not hard to hear comments from local cadres in Châu La Biên that Lò Vi An had arranged for his family members and his followers to hold important positions in Châu La Biên's local state system. A retired provincial leader, one of Lò Vi An's previous political opponents in Châu La Biên, criticised him strongly as 'a corrupted nepotistic leader'. He said, 'Within only the two first years of his presidency, he [Lò Vi An] promoted more than 20 family members and his followers to be provincial department and district leaders. It was unacceptable because this province is not his own kingdom.' Nevertheless, Lò Vi An responded calmly when I discussed those complaints with him. He believed he did not do anything wrong because he simply needed capable staff, who he could trust, to work with. He explained: 'They [his political opponents] complained about it because they know nothing about $\hat{e}$ kip [being a team player]. And see, they [persons he promoted] have been working well and are deserving of their positions.'

Discussing his family members' promotion, Lò Vi An contended that 'all decisions were made by a collective board of provincial leaders. I did not sign solely on any of those promotion decisions'. Similarly, Lò Vi Loan - a sister of Lò Vi An - who was general director of a provincial department in Châu La Biên, referred to the saying, 'a hand cannot cover the sun' ('một tay làm sao có thể che được mặt trời'), when she asserted that her position was proposed by the Provincial Standing Committee and approved by the Provincial People's Council. In fact, the use of 'collective decisions' is common in politics in Vietnam. It is one of the most popular political tricks used by state officials, making it difficult to find the particular individuals responsible for any given issue. Even at the highest level of Vietnam's political system, Mr Nguyễn Sinh Hùng — the Chairman of the National Assembly - recently raised a very debatable argument that no one, including himself as chairman or any other National Assembly members, can be held responsible for wrong decisions made by the National Assembly. He explained this by asserting that 'the Vietnam National Assembly represents the people so it is the people who are responsible' ('Quốc hội là dân, mà dân quyết sai thì dân chịu chứ ai?') (Linh 2014). Even though Lò Vi An's family members' occupation of positions in the local state of Châu La Biên was criticised strongly, his 
political opponents could hardly do anything about it, because Lò Vi An had cleverly used the 'collective mechanism' (cơ chế tập thể) of the Vietnamese state in forming and strengthening his entourage network.

In general, Lò Vi An was proud of his siblings, especially Lò Vi Loan, who rose up to become a provincial department leader. In conversation among Lò Vi An's family, I heard that Lò Vi Loan had great potential to be promoted as Vice President of the Provincial People's Committee for the next term. To be fair to Lò Vi Loan, who I have known for a long time, she is certainly a smart female Thai leader. Lò Vi An believed that Lò Vi Loan inherited her decisive and determined character 'like a man' - from their father. Indeed, straightforward as she is, Lò Vi Loan told me clearly via phone when I contacted her for an interview: 'If you want to ask about my work, come here to my office. Otherwise, I will see you at home.' I decided to see her at her office, not simply because of her work, but also because I was curious to know about her work setting. Since she appeared to me as a traditional Thai lady who normally dresses in Thai costume and speaks Thai at home with her family members, I was a bit surprised to find that Lò Vi Loan's office exhibited no trappings of Thai culture except her own personal outfit; as usual, she was dressed in a Thai skirt. Speaking to me in Thai, she said, 'I am going to have a meeting in an hour so you don't have to stand on ceremony like an outsider'.

Since we did not have much time, our conversation went straight to the topic of Thai cadres in Châu La Biên. I asked for her opinion about the criticism of Lò Vi An as corrupt owing to his promotion of so many of his family members to leading positions in the local state. Lò Vi Loan defended him, saying:

It is politics: opponents criticise you for anything you do regardless of whether it is right or wrong. My brother was in fact too strict with our family members when he was president here. Look at Lò Trang [Lò Vi An's other sister]: she has been deputy head of a division for years. If he had intended to do such a thing [promoting family members], she [Lò Trang] wouldn't still be there now.

However, Lò Vi Loan later confirmed indirectly that Lò Vi An had promoted several family members and followers during the time he had been working as President of Châu La Biên. She argued that the majority of the Châu La Biên Province population is Thai (60 per cent), yet the percentage of Thai cadres in the local government is much 
lower than that of the population. ${ }^{11}$ Hence, 'There was nothing wrong with Lò Vi An's decisions to promote Thai cadres into management positions. Many provincial leaders do the same thing with their families.' I asked her for an example of this and she promptly listed several cases in which the provincial leaders of Châu La Biên used their power to promote their relatives. She even told me the story of an informal negotiation that happened between Lò Vi An and the former Secretary of the Châu La Biên Communist Party for the purpose of promoting and arranging provincial personnel. It sounded as if a lot of informal negotiations had been going on in Châu La Biên between different powerful leaders and/or different clans. For example, she said:

I am surprised that he [the mentioned retired provincial leader of Châu La Biên] dared tell you about it [Lò Vi An's support to his family members and followers]. His sister-in-law was my deputy [at district level], so he negotiated with my brother that if I moved to provincial level, his sister-in-law should be the one to replace me ... and indeed, she did.

Lò Vi Loan's conversation with me seemed to be more open after we chatted about studying in Australia, as she was planning to send her son to study overseas. She tried to convince me that having family members in the system is very normal and common. According to her, everyone would support their family members, including the nation's top leaders. If they don't have their family members working in the state system, they will support their family members who are working in the private sector to form different business connections. 'Then they might be even more corrupt', she said.

Interestingly, she might have forgotten her youngest brother, Lò Lam, when making this argument. Lò Lam is a case in point, because he was not working for any state agency. He was connected with the group of Thai cadres, including his brothers and sisters, not only by kinship relations but also business relationships. In his early 40s, Lò Lam, according to himself, is literally a 'jobless man', because he does not work for either a state agency or any private company. In Lò Vi An's

11 There are currently 21 ethnic groups in the northwest provinces of Vietnam. However, since the Thai people comprise one of the majority indigenous groups of the region, this northwest region was named the Thai-Meo Autonomous Zone from 1955 until 1963. As a consequence, the Thai cadres remain one of the most dominant groups in the local state system in the northwest provinces. 
eyes, 'He was over-indulged by my parents. He was spoiled because he got whatever he wanted since he was a boy.' Lò Vi An normally depicted Lò Lam as a failed member of his family because 'he does not belong to any organisation'. Nonetheless, I was curious about what Lò Vi An told me about his youngest brother, and why he kept saying that Lò Lam is a spoiled man.

Having once worked for a local branch of Electric Power of Vietnam, Lò Lam had quit his job in 2002 to work in an infrastructure building firm with his friends. He spoke candidly with me while he was showing me around the town of Châu La Biên, saying: 'Everyone has their own way of life. My ultimate purpose is earning money to raise my family.' Without a doubt, Lò Lam is a wealthy Thai man. He has a big house, drives an expensive car, and was able to send both his children to China to study. His 'money-earning' career seems very successful, in contrast to how he was described by his brother.

I observed that Lò Lam was very well connected, not only with Lò Vi An, but also with other group members. In reality, Lò Lam was working informally for a friend who runs a big construction company. During my second trip to Châu La Biên, Lò Lam even invited me, as his driving companion, to join him and Cầm Chung in travelling to Châu Quỳnh to prepare for a construction bid there. Although he is not a state official like his brothers and sisters, Lò Lam is a practical man who has greatly benefited from the network of Thai cadres grouped around his brother. Similar to what Lường Trung had been doing, Lò Lam basically acted as a broker between state investment officials and private construction companies. In particular, he takes advantage of his family relationships to influence Thai cadres in Châu La Biên to give building contracts to the company. In return, the company had to share its profit with him, and perhaps also to other local authorities via Lò Lam, even though he had nothing to do with implementing those contracts. In short, Lò Lam is an infrastructure construction middleman in Châu La Biên.

In fact, such a 'middleman' - or trung gian, môi giới or even cò in Vietnamese - is quite common. According to Kerkvliet, a problem in village-state relations in Vietnam since the time of de-collectivisation has been that, 'due to insufficient resources and other inadequacies, the actual administrative capacity of the state to coordinate programs and implement policies is considerably less than it would require' 
(Kerkvliet 1995:399). Lò Lam's work as a construction middleman in Châu La Biên indicates that the Vietnamese government is still ill-equipped when it comes to running a market-oriented economy. It allows Lò Lam to make himself useful to state officials such as his brothers and sisters, who do not want to be directly involved in a 'sensitive' area like infrastructure development investment, and to private contractors, who cannot otherwise establish their credentials with powerful state leaders. In other words, Lò Lam plays the role of middleman among the Thai people, which, according to the theory of middleman, plugs the status gap between the state and private sector at the local level, acting as broker between them (Bonacich 1973).

Most Thai leaders I met in Châu La Biên, such as Cầm Chung, Lường Trung, Lò Vi Loan, Nguyễn Toàn and Lường Ly, would make a lively endorsement of Huy's statement that 'provincial officials are mostly like brothers in a family'. It is true that most of them are connected with Lò Vi An via a classic patron-client relationship:

In which an individual of higher socioeconomic status [patron] uses his own influence and resources to provide protection or benefits, or both, for a person of lower status [client] who, for his part, reciprocates by offering general support and assistance, including personal services, to the patron (Scott 1972:72).

However, these persons are also tied to each other within the local state as members of an extended family, which enables them to manipulate the local state and maintain their family influence in Châu La Biên. I found that this grouping of Thai cadres has been effectively using the state of Vietnam as their base, and government policies and programs as their means to strengthen their family connections. By networking with each other, they have been able to practice, maintain, and develop Thai forms of relatedness within the state of Vietnam.

\section{The Thai Cadre Entourage as a 'Fishing Net' of Relations}

A formalist depiction of the nature of Vietnamese state authority might easily conclude that it conforms to what Weber has described as legal or bureaucratic authority (Weber 2009:56-65). In principle, the Vietnamese state has long been following the model of a law-based state 
(nhà nước pháp quyền), which is based on a legal authority type with a bureaucratic administrative system (Gillespie 2013:676). In addition, the Vietnamese state is also commonly considered in the literature as an authoritarian regime (Wischermann 2011:7; Joseph 2007), with uniform national institutions that enable the ruling party to project its power homogeneously throughout society in a manner that has been described as 'mono-organizational socialism' (Thayer 2009:3). Koh notes that 'the view that the Vietnamese party-state dominates, leaving very little space for society', has prevailed for some time (Koh 2001:369).

Nevertheless, the network of Thai cadres in northwest Châu La Biên who gather around Lò Vi An reveals greater complexity in the nature of Vietnamese state authority. The connections built up by the cadres, grouped around a senior Thai leader, enable them to exert influence and wield power in a mode that could be called northwest Thai entourage politics. By practising it at the local state level in Châu La Biên, northwest Thai cadres have been flexibly assimilating the Vietnamese state in their locale to a traditional mode of authority that is, according to Weber (2009), generally patrimonial in form, and derived from traditional customs and established norms.

Indeed, Lò Vi An, who was commonly addressed as 'big brother' of the group, used his skill, political influence, and access to state power to shape and connect his family members and followers into an entourage of Thai cadres. With him as the central node person, other members, consisting of about 15 people working in different agencies, were interlinked with each other around Lò Vi An. This Thai grouping consists of a 'meshwork' (Ingold 2011) of related members connected to each other in relations of kinship, adoption, patron-client ties and mutual obligation. Each of them has his or her own ties with the top person, as well as other contiguous members, bringing into form a distinctive constellation of power within the state of Vietnam that is as strong and resilient as a Thai-style fishing net. The nature of this network has several prominent elements, as elaborated below.

One of the most obvious characteristics of this Thai 'fishing net' cadre network in Châu La Biên is the hierarchical relations among its interlinked members. Several factors help identify the status of members, such as age, gender, and position in the state. However, the most dominant factor, which controls their hierarchical positions in 
the network, is proximity to the leader. For example, Lường Ly, as a younger sister of Lường Trung, basically has a lower status than Lường Trung, even though her position in the local state system is higher. Lò Lam has no official position, but is high in the network. In general, I found through different parties and feasts in Châu La Biên that one of the easiest ways to see the hierarchy among Thai grouping members is by observing their sitting positions around dining tables. It is not much different to traditional Thai seating rules in so-called 'feudal' times, described by Cam Trong several decades ago (Cam Trong 1978:247-248). ${ }^{12}$ Accordingly, the closer a person sits to the highest leader of the table, the higher ranking they have in the group. ${ }^{13}$

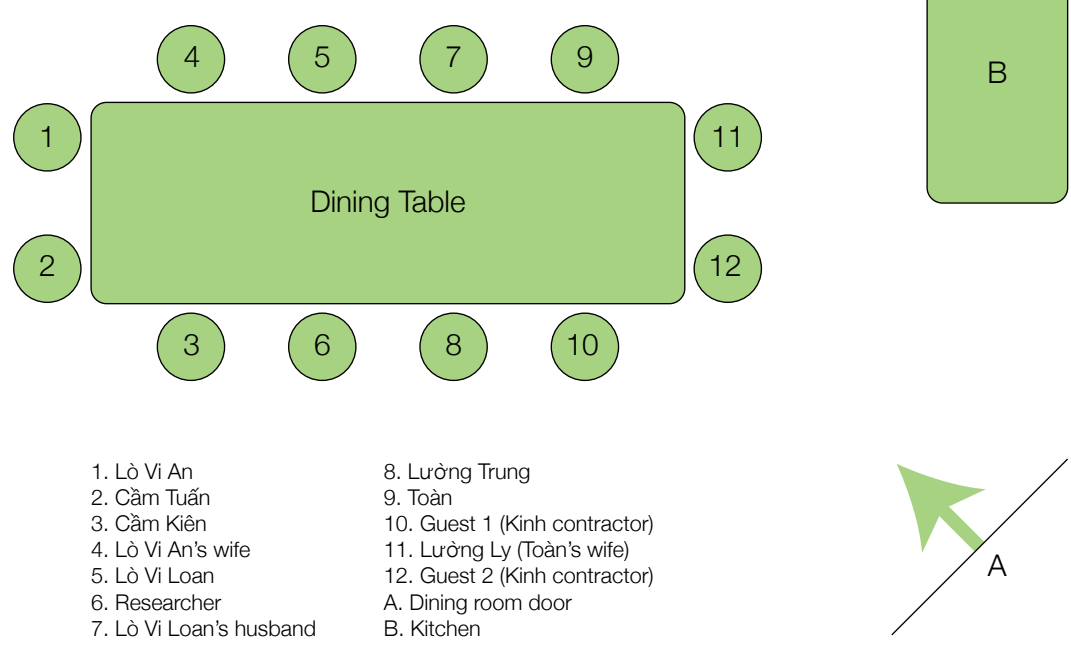

Diagram 1: Dining positions at Lò Vi An's house.

A second important feature of this Thai entourage is the obligation among members. All members share mutual obligations with both Lò Vi An and other members, including Nguyễn Toàn and Cầm Chung,

12 In Cam Trong's (1978) book about Thai people in northwest Vietnam, the author generalises that the term 'feudal time' (thời phong kiến) refers to the Chau-Muong administrative system of the Thai people in relation to Vietnam's pre-colonial state and the French colonial state of Indochina before the Vietnamese revolution in 1945.

13 The seat of the highest-status person is normally located opposite the door of the dining room. 
whose connections with Lò Vi An had originated in patron-client relations. Here we can find elements of what Scott discerns in his overview of patron-client politics:

There is an imbalance in exchange between the two partners which expresses and reflects the disparity in their relative wealth, power, and status. A client, in this sense, is someone who has entered an unequal exchange relation in which he is unable to reciprocate fully. A debt of obligation binds him to the patron. (Scott 1972: 93)

In this entourage group, Nguyễn Toàn, Cầm Chung, and Lò Vi An have developed their connections beyond such relations of debt and obligation into kin-like relations infused with sentiment and trust. The 'patron' — Lò Vi An — has assumed the same responsibilities of taking care of Cầm Chung and Nguyễn Toàn as he would his real family members. Obligation weighs most heavily upon the shoulders of the entourage leader, for it is to him that other members of the group look to advance the fortunes of the whole group.

The presence of adoptive members in this group also points to the open, synthetic, and generative nature of this network whose membership criteria are not confined to tradition, inheritance, or ascription alone. Membership and rank in this Thai cadre entourage are earned, consolidated, and reinforced, most notably through displays of loyalty from its subordinate members and of performance from its superordinate leader. As I was to discover, new members can be incorporated into the entourage through invitations to partake in shared meals and drinking sessions, and through inclusive modes of address and collective self-reference, by which means the network can be flexibly extended. Displays of deference, mutuality, and loyalty, as well as facility in the familial idioms of the network, can consolidate one's position in the network, while rank can be enhanced through loyalty and displays of efficacy in navigating the world beyond the entourage and attracting resources to the group. Perhaps the most obvious arena for attaining and symbolising rank in this Thai cadre 
entourage is the hosting of communal meals, whose size, lavishness, and conspicuously traditional nature earn significant prestige for the entourage leader and bind network members to him. ${ }^{14}$

Of particular note are the strong sentiments of esteem that exist among network members, channelling the loyalties of even far-flung entourage members towards the central node person. For instance, the sincere appreciation by Lường Chung for what Lò Vi An had done in developing Châu La Biên would be more or less comparable to the charismatic type of authority defined by Max Weber as a 'certain quality of an individual personality, by virtue of which he is set apart from ordinary men and treated as endowed with supernatural, superhuman, or at least specifically exceptional powers or qualities' (Weber 2009:329). It would appear that, for many Thais in his region, Lò Vi An embodies qualities of a Southeast Asian-style 'man of prowess' (Wolters 1999) owing to his perceived efficacy as a leader in attracting state investment and enabling careers in his region. Additionally, he embodied in his person the 'magic of the state' (Taussig 1997). By virtue of his father's revolutionary pedigree, his intensive Vietnamese schooling, and his close association with Vietnamese state agents such as Vietnamese teachers and national leaders, he was imbued with the aura of national state power.

A sense of belonging binds the members of the Thai cadres group around Lò Vi An to each other. This sentiment could be considered as one of the prime bases for building trust between network members. This is the gist of Lò Vi An's justification for his decisions to recruit and promote his followers into different important leading positions in Châu La Biên Province. Another example of how belonging is significant to being connected was Lường Trung's insistence on describing two infrastructure development contractors as his 'brothers' during dinner at Lò Vi An's house. Such modes of address and self-reference

14 Because of the difference in the density of his social relationships between Hà Nội and Châu La Biên, Lò Vi An felt disappointed in the working environment with his colleagues in Hà Nội during the first years of his posting. Having once been a provincial leader in Châu La Biên, where he had a crowded entourage around not only at work but also at home, Lò Vi An was initially shocked by the fact that he had none of his followers in Hà Nội. According to him, 'there is no feeling (không có tình cảm) among his office mates, and people are cold and too competitive with each other'. One example that Lo Vi An kept mentioning was the difference between his family meals in Hà Nội and in Châu La Biên: 'Whenever I have dinner at home up there [Châu La Biên], we set at least two dining tables for guests. Look at what we have here [Hà Nội], only us [he and his wife] two old people eating together.' 
construct a boundary between group members as 'brothers in the one family', and those who are 'outsiders'. Commensal acts of dining and drinking together, and ritual declarations of kinship that accompany such acts further consolidate a sense of togetherness and belonging. The identity of the dishes they consume, often prepared and referred to self-consciously as 'real' or 'traditional' Thai food, also reinforces this sense of belonging. Through these acts, the entourage is given substance as a corporate or inter-corporeal group, whose members routinely provide sustenance for each other and become one of the same substance.

A final feature of this entourage, which was only faintly visible when I conducted my fieldwork, is its apparent portability. In late October 2014, I realised that I had missed three calls from Nguyễn Toàn, who was phoning from Vietnam. A short email from him on the same day, with his working address at the bottom, informed me that he had now started working for a central agency in Hà Nội. During our subsequent phone conversation, I was informed that Lò Vi Loan and her husband would be the next people to move to work in Hà Nội after Nguyễn Toàn and Cầm Chung. Even though both Nguyễn Toàn and Cầm Chung received support from Lò Vi An to move to work in Hà Nội, it is too early to say that Lò Vi An is reforming his Thai entourage right in the heart of a central agency of the Vietnamese state. Nevertheless, these initial moves illustrate the tendency of this northwest Thai entourage to converge around a central node person. This tendency can be observed in the expectations expressed by Lò Vi Loan, during my interview at her office, who was anticipating that Lò Vi An would help to support Cầm Chung to return to the provincial state of Châu La Biên from his position at the district level in Châu Quỳnh.

This description of the elements that make up the Thai cadre network around Lò Vi An provides a sense of the main generative principles underlying Thai entourage politics in the northwest of Vietnam. This grouping of influential Thai cadres is aligned in a ranked meshwork of relations, obligations, and sentiments around a charismatic leader. The entourage around him is characteristically open, flexibly accommodating, markedly performative, and, potentially, has the capacity to extend itself geographically in the wake of its leader's movements. 


\section{Conclusion}

The strength and resilience of this network of Thai cadres in the heartland of northwest Vietnam leads us to question characterisations of modern Vietnamese state power as homogeneous or monolithic in nature. Researching the Cham and Khmer peoples in southwestern Vietnam, Philip Taylor finds that religious institutions such as Islamic mosques and Theravada Buddhist temples are a compelling nexus of communal authority for these groups that rival the authority commanded by the central state. Many Khmer localities have a historically autonomous quality, with the wats functioning as multifaceted communal institutions and as pivotal nodes between the state and local society (Taylor 2014:17). In this chapter, I use a network of northwest Thai cadres grouped around a powerful Thai leader to illustrate another mode of governance within the Vietnamese state system, one which I call northwest Thai entourage politics. Accordingly, I argue that Vietnam is not a uniform state with a single form of authority, but that the state is a politically aggregate entity comprised of heterogeneous forms of authority.

What I am calling northwest Thai entourage politics comprises several key elements including hierarchy, mutual obligation, openness, performativity, sentiment, belonging, and a tendency of convergence to a central 'node' person. Contemporary Thai people of the northwest also have a relationship with central state power located in Hà Nội which is strikingly similar to that of pre-revolutionary times. In the precolonial era, in spite of offering loyalty to Vietnam's court and engaging in relations with influential centres in neighbouring Thailand, Yunnan, and Laos, the Thai people of Vietnam's northwest for many centuries experienced autonomy under the rule of their local chiefs (McAlister 1967; Cam Trong 1978; Le Failler 2011). From the late nineteenth century when the French seized power from the Vietnamese feudal state, the northwest Thai region came under the rule of the Đèo family, who acted as delegates in the region for French colonial authority, and who even accrued enough power to form their own Tai Federation from 1948 to 1953 'by exploiting the French administrative framework' (Le Failler 2011:63; see also Lentz 2011). In other words, the current situation of northwest Thais has precedents in the past practices of northwest Thai elites who were able to accommodate with the lowland state in Vietnam and act as its 
delegates to substantively maintain their local power. These research findings suggest that the state of Vietnam is not all powerful in its relations with ethnic minority groups, and that Koh is right when he concludes, 'there is much space in which society can manoeuvre and rework the state's boundaries to society's benefit' (Koh 2001:370).

We have seen that the northwest Thai cadre network cannot be trivialised or explained away as an expression of reactive traditionalism, localism, or disconnection from contemporary state initiatives. It has supple social effects, with the capacity to cast its members into the heart of the Vietnamese state system, and to capture state resources and draw them back to the advantage of network members. The fishing net metaphor used to describe the contours of Thai entourage politics aptly describes these dual processes. The political influence wielded by the Thai cadre network is such that some have alleged it to be corrupt or nepotistic. While potentially such 'special interests' (nhóm lợi ích) can be construed as threatening to the modernist principles of rationality, equity, merit, and transparency espoused by the contemporary Vietnamese state, we can question whether political sovereignty is eroded by Thai entourage politics or is, in fact, consolidated by them. Not only does the entourage benefit from the state, but the state benefits from the entourage, which provides a means for the state to articulate with local Thai society, invest in the locality, ensure compliance, and reward performance. Before raising alarm about the erosion of the bureaucratic polity by the operation of this distinctive non-normative network of power, we ought to pose one question: has Vietnamese state power ever been exercised in the northwest uplands in any other way?

\section{References}

Baulch, Bob, Nguyen Thi Minh Hoa, Nguyen Thi Thu Phuong and Pham Thai Hung 2010, Ethnic Minority Poverty in Vietnam, UNDP, Hanoi.

Baulch, Bob, Hung T. Pham and Barry Reilly 2012, 'Decomposing the Ethnic Gap in Rural Vietnam, 1993-2004', Oxford Development Studies, vol. 40. no. 1, pp. 87-117. 
Blackburn, Keith, Niloy Bose and M. E. Haque 2006, 'The Incidence and Persistence of Corruption in Economic Development', Journal of Economic Dynamics and Control, vol. 30, no. 12, pp. 2447-2467.

Bonacich, Edna 1973, 'A Theory of Middleman Minorities', American Sociological Review, vol. 38, no. 5, pp. 583-594.

Bui Thi Minh Hang, Pepijn Schreinemachers and T. Berger 2013, 'Hydropower Development in Vietnam: Involuntary Resettlement and Factors Enabling Rehabilitation', Land Use Policy, vol. 31, pp. 536-544.

Cam Trong 1978, Người Thái ở Tây Bắc Việt Nam [The Thai in Northwest Vietnam], Social Sciences Publishers, Hanoi.

Condominas, Georges 1990, From Lawa to Mon, from Saa' to Thai: Historical and Anthropological Aspects of Southeast Asian Social Spaces, Research School of Pacific and Asian Studies, The Australian National University, Canberra.

Ensaria, Nurcan and Susan Murphy 2003, 'Cross-cultural Variations in Leadership Perceptions and Attribution of Charisma to the Leader', Organizational Behavior and Human Decision Processes, vol. 92, pp. 52-66.

Evans, Grant 1992, 'Internal Colonialism in the Central Highlands of Vietnam', SOJOURN: Journal of Social Issues in Southeast Asia, vol. 7, no. 2, pp. 274-304.

Farouk, Omar and Hiroyuki Yamamoto 2008, Islam at the Margins: The Muslims of Indochina, CIAS, Kyoto, Japan.

Gillespie, John 2013, 'Jurifidication of Cause Advocacy in Socialist Asia: Vietnam as a Case Study', Wisconsin International Law Journal, vol. 31, pp. 672-700.

Hanh, Duong Bich 2008, 'Contesting Marginality: Consumption, Networks, and Everyday Practice Among Hmong Girls in Sa Pa, Northwestern Vietnam', Journal of Vietnamese Studies, vol. 3, no. 3, pp. 231-260.

Hardy, Andrew 2005, Red Hills: Migrants and the State in the Highlands of Vietnam, NIAS Press, Copenhagen. 
Hickey, Gerald C. 1982, Free in the Forest: Ethnohistory of the Vietnamese Central Highlands, 1954-1976, Yale University Press, New Haven.

Horstmann, Alexander and Reed Wadley 2006, 'Introduction: Centering the Margins in Southeast Asia', in Alexander Horstmann and Reed Wadley (eds), Centering the Margins: Agency and Narrative in Southeast Asian Borderlands, Berghahn Books, New York, pp. 1-24.

Ingold, Tim 2011, Being Alive: Essays on Movement, Knowledge and Description, Routledge, London.

Joseph, Samantha 2007, 'Ethnic Minorities in Vietnam', Indigenous Law Bulletin, vol. 7, no. 1, pp. 123-125.

Kerkvliet, Benedict J. Tria 1995, 'Village-State Relations in Vietnam: The Effect of Everyday Politics on Decollectivization', The Journal of Asian Studies, vol. 54, no. 2, pp. 396-418.

Keyes, Charles 1975, 'Kin Groups in a Thai-Lao Community', in G. William Skinner and A. Thomas Kirsch (eds), Change and Persistence in Thai Society, Cornell University Press, Ithaca, New York, pp. 274-297.

Koh, David 2001, 'State-Society Relations in Vietnam: Strong or Weak State?', in Daljit Singh and Anthony L. Smith (eds), Southeast Asian Affairs 2001, Institute of Southeast Asian Studies, Singapore, pp. 369-386.

Le Failler, Philippe 2011, 'The Đèo Family of Lai Châu: Traditional Power and Unconventional Practices', Journal of Vietnamese Studies, vol. 6, no. 2, pp. 42-67.

Lentz, Christian C. 2011, 'Making the Northwest Vietnamese', Journal of Vietnamese Studies, vol. 6, no. 2, pp. 68-105.

Linh Thư 2014, 'Quốc Hội Là Dân, Dân Quyết Sai Dân Chịu Chứ Kỷ Luật Ai?' ['The National Assembly is the People and who else but They Bear Responsibility for its Mistakes?'], Vietnamnet, 11 April 2014, available at vietnamnet.vn/vn/chinh-tri/169988/ qh-la-dan--dan-quyet-sai-dan-chiu-chu-ky-luat-ai-.html, accessed 17 November 2015. 
Lord, Robert G., and Karen J. Maher 2002, Leadership and Information Processing: Linking Perceptions and Performance (second edition), Taylor \& Francis, London.

McAlister, John 1967, 'Mountain Minorities and the Vietminh: A Key to the Indochina War', in Peter Kundaster (ed.), Southeast Asian Tribes, Minorities and Nations, Princeton University Press, Princeton, pp. 746-770.

McElwee, Pamela 2004, 'Becoming Socialist or Becoming Kinh?: Government Policies for Ethnic Minorities in the Socialist Republic of Vietnam', in Christopher R. Duncan (ed.), Civilizing the Margins: Southeast Asian Government Policies for the Development of Minorities, Cornell University Press, Ithaca, pp. 182-213.

McLeod, Mark W. 1999, 'Indigenous Peoples and the Vietnamese Revolution, 1930-1975', Journal of World History, vol. 10, no. 2, pp. 353-389.

Michaud, Jean 2009, 'Handling Mountain Minorities in China, Vietnam and Laos: From History to Current Concerns', Asian Ethnicity, vol. 10, no. 1, pp. 25-49.

Michaud, Jean (ed.) 2013, Turbulent Times and Enduring Peoples: Mountain Minorities in the South-East Asian Massif, Curzon Press, Richmond, Surrey.

Moerman, Michael 1969, 'A Thai Village Headman as a Synaptic Leader', The Journal of Asian Studies, vol. 28, no. 3, pp. 535-549.

Ngo Vinh Long 1997, 'Ethnic Pluralism, Multiculturalism and Development in Vietnam', New Political Science, vol. 19, no. 1-2, pp. 139-152.

Nguyễn Khánh Toàn 1975, 'Một vài quan điểm cơ bản cần được quán triệt trong quá trình xây dựng danh mục các Dân Tộc Thiểu Số ở Miền Bắc Nước ta' ['Some Fundamental Perspectives to Clarify in Constructing the List of Ethnic Minorities in the North of our Country'], in Bế Viết Đẳng (ed.), Về vấn đề Xác định Thành Phần các Dân Tộc Thiểu Số ở Miền Bắc Việt Nam [The Problem of Identifying Ethnic Minority Groups in Northern Vietnam], Nhà xuất bản Khoa học xã hội, Hanoi, pp. 3-9. 
Nguyen Thuy Thu and Mathijs A. van Dijk 2012, 'Corruption, Growth and Governance: Private vs. State-owned Firms in Vietnam', Journal of Banking and Finance, vol. 36, no. 11, pp. 2935-2948.

Salemink, Oscar 2003, 'Enclosing the Highlands: Socialist, Capitalist and Protestant Conversions of Vietnam's Central Highlanders', paper presented to 'Politics of the Commons: Articulating Development and Strengthening Local Practices' conference, Chiang Mai University, 11-14 July 2003, available at dlc.dlib. indiana.edu/dlc/handle/10535/1787.

Salomon, Matthieu, and Vu Doan Ket 2007, 'Doi Moi, Education and Identity Formation in Contemporary Vietnam', Compare: A Journal of Comparative and International Education, vol. 37, no. 3, pp. 345363.

Scott, James C. 1972, 'Patron-Client Politics and Political Change in Southeast Asia', The American Political Science Review, vol. 66, no. 1, pp. 91-113.

Scott, James C. 2009, The Art of Not Being Governed: An Anarchist History of Upland Southeast Asia, Yale University Press, New Haven.

Szasz, Margaret C. 2001, Between Indian and White Worlds: The Cultural Broker, University of Oklahoma Press, Oklahoma.

Taussig, Michael 1997, The Magic of the State, Routledge, New York and London.

Taylor, Philip 2008, 'Minorities at Large: New Approaches to Minority Ethnicity in Vietnam', Journal of Vietnamese Studies, vol. 3, no. 3, pp. 3-43.

Taylor, Philip 2014, The Khmer Lands of Vietnam: Environment, Cosmology and Sovereignty, NUS Press, Singapore.

Thayer, Carlyle 2009, 'Vietnam and the Challenge of Political Civil Society', Contemporary Southeast Asia, vol. 31, no. 1, pp. 1-27.

Turner, Sarah 2007, 'Trading Old Textiles: the Selective Diversification of Highland Livelihoods in Northern Vietnam,' Human Organization, vol. 66, no. 4, pp. 389-404. 
Vaddhanaphuti, Chayan 2005, 'The Thai State and Ethnic Minorities: From Assimilation to Selective Intergation', in Kusuma Snitwongse and Scott Thompson (eds), Ethnic Conflicts in Southeast Asia, ISEAS Publications, Singapore, pp. 151-166.

Weber, Max 2009, The Theory Of Social and Economic Organization, Free Press, New York.

Wischermann, Jörg 2011, 'Governance and Civil Society Action in Vietnam: Changing the Rules From Within - Potentials and Limits', Asian Politics and Policy, vol. 3, no. 3, pp. 383-411.

Wolf, Eric R. 1956, 'Aspects of Group Relations in a Complex Society: Mexico', American Anthropologist, vol. 58, no. 6, pp. 1065-1078.

Wolters, Oliver William 1999, History, Culture, and Region in Southeast Asian Perspectives, Cornell Southeast Asia Program Publications, Ithaca, New York. 
This text is taken from Connected and Disconnected in Viet Nam: Remaking Social Relations in a Post-socialist Nation, edited by Philip

Taylor, published 2016 by ANU Press, The Australian National University, Canberra, Australia. 